\title{
The Use of Expressive Arts Therapy in Understanding Psychological Issues of Juvenile Delinquency
}

\author{
Sh Marzety Adibah Al Sayed Mohamad ${ }^{1} \&$ Zakaria Mohamad $^{1}$ \\ ${ }^{1}$ University Malaysia Terengganu, Kuala Terengganu, Malaysia \\ Correspondence: Zakaria Mohamad, University Malaysia Terengganu, 21030 Kuala Terengganu, Malaysia. \\ E-mail: zek@umt.edu.my
}

Received: December 11, 2013

Accepted: March 3, 2014 Online Published: April 29, 2014

doi:10.5539/ass.v10n9p144

URL: http://dx.doi.org/10.5539/ass.v10n9p144

\begin{abstract}
This phenomenological research design of qualitative study was conducted to understand the experiences of creative relationship during Expressive Arts Therapy group counseling session. A total of seven girls between the ages of 12-18 years who have been involved in juvenile delinquent behaviors were selected using purposive sampling groups. Interviews, observations and document analysis were conducted for data collection. Validity and reliability of the process were done through triangulation, peer review and audit trail. Data analysis was made to give overall meaning, meaning of discrimination unit, initial transfer of meaning units, transfer units psychological meaning, structure of individual psychology, and general psychological structure. The results showed that there are some psychological issues that have to be shared and expressed by all subjects in the study. The study participants shared their feelings such as anger, revenge, hatred, guilt and regret, disappointment and sadness, rebellious, begging for affection, looking for happiness, satisfaction and enjoyment of life, issues of low self-esteem and other issues concerning trauma and emotional disorders that have been experienced in their lives. In conclusion, this study provides some implications in terms of techniques and practices of counseling in Malaysia and the need for further research.
\end{abstract}

Keywords: expressive arts therapy, juvenile delinquency, psychological issues, phenomenology, group counseling

\section{Introduction}

In Malaysia, many teenagers are involved with delinquent behaviours such as misbehaviours in school, drug abuse, illegal street racing, snatch thefts, bullying, wild sex parties, gambling, concealed carry, and many other delinquencies including murder. Fauziah (2005) explained that this situation is a serious social issue. According to her, the social issue which is also known as delinquency among teenagers has become an unstoppable phenomenon and continue to spread from time to time.

The amount of teenagers involved with delinquency is reported to be increasing each year. According to the statistics provided by Department of Social Welfare Malaysia, in 2004 teenage-related crimes including delinquent behaviours had increased to 6056 cases and it rose to 7201 cases in 2005 (Department of Social Welfare Malaysia , 2006). Other than that, the number of arrested students aged between 13 to 18 years old has also shown increase. The crime investigation unit statistics revealed that throughout year 2007, 1836 crime cases were reported with 3383 students being arrested. The number has risen with the increase of 382 cases last year, which amounted to an overall of 2218 cases last year with 3725 students arrested (Malaysia Crime Prevention Foundation, 2009).

The involvement of teenagers in the crime scene has clearly shown us that they have been influenced with unhealthy behaviours that could cause negative effects psychologically. Dembo and Schemeidler (2003) explained that the relation between delinquency and teenage emotional problems. They stated that teenage involvement with criminal cases is often linked to their emotional problems which eventually drags them to social ills, like delinquency. Delinquent behaviours among teenagers is also caused by their inability to control their emotions (Dembo \& Schmeidler, 2003). Teenagers' unstable state of emotions is often associated with teenagers' identity. At this stage, they are often labeled as emotional-driven and moody (Potter and Jensen, 2003). In a study done by Rohany, Zainah, Rozainee and Fatimah (2011), it is discovered that most teenagers involved with delinquent behaviors are under stress and highly disturbed in their thinking. 


\section{Expressive Arts Therapy}

Creative Arts or Expressive Arts is a passage way in providing comfort to children and teens to communicate with adults about their internal and external world. Art is often used to understand individual experience, especially adolescents, in an effort to overcome the confusion, grief and inner conflict. Art is also a potential tool for healing and curing (Finn, 2003). The use of this art provides a path or way for self-expression, communication and growth. This creative process can eliminate the emotional conflicts and foster self-awareness and healing (Deaver, 2002).

The use of Expressive Arts Therapy can be a means for adolescents to communicate comfortably, and has the potential to be a recovery tool (Finn, 2003). Rogers (1993) defines Expressive Arts Therapy as an experience of using art as a therapeutic tool. Malchiodi (2008) defines the Expressive Arts Therapy as the use of various types of art such as dance, drama, painting, music, painting, photography, sculpture, writing, bibliotherapy, theaters and sand castles embedded in the context of psychotherapy, counseling, rehabilitation or treatment. Furthermore, sometimes Expressive Arts Therapy is also referred to as a creative or integrated art therapy when it is intended to be combined treatments (Knill, Poala, Baba \& Fush, 1995; Estrella, 2005).

Expressive Arts Therapy can help clients to find and give real meaning in their lives through the experience of creative relationship. Meanings which are sought after and obtained would motivate individuals to get high level of excitement and confidence in pursuing their life. Lantz and Gyamerah (2002) stated that the use of art is a good way to help clients to find purpose and meaning in life. Works of art that have been produced by clients can help therapists to identify elements of reflection in the works of art as well as helping the client to recognize, realize and appreciate the potentials that are more meaningful in their lives through creative relationship (Lantz \& Gyamerah, 2002).

The participants in this study shared their experiences on creative stimulation through the use of Expressive Arts Therapy in group counseling. Creative stimulation has prompted the participants to reflect on and relate the problems faced by those with past experiences. Rubin (2001) also explained that the sentiments and ideas are better expressed using the art of words. Art and creativity also provide unique opportunities to see, experience and feel all internal difficulties to any crisis experienced by someone who can not translate them in words. Other than helping the adolescents in the process of identifying, understanding and interpretation of their experience, it can also provide space and make way for creative process in putting meaning between the sequences of events in their lives.

Expressive art is an exquisite method to express oneself through symbols and metaphors; indirectly saying how one really feels towards any individual that he/she hates. It is often a way of getting negative feelings out of the system without hurting anyone.

A direct work with emotions is an essential activity in Expressive Art Therapy. Emotions are appreciated as a moving force or encouragement for our thoughts, behaviours, trust and self-reliance (Peorson \& Wilson, 2009). Emotional healing will direct us towards desired changes (Peorson \& Wilson, 2008). This contrasts to the use of other techniques, such as Rational Emotive Behavioral Therapy (REBT), an important perspective in Cognitive Behavioral Therapy (CBT), in which emotional cognitive and behavioural methods are used for clients' changes and treating mental disorder. CBT is used effectively in treatments and in improving mental health for both individuals and groups (Mahmoud Roghanchi, Abdul Rashid Mohamad, See Ching Mey, Khoda Morad Momeni, \& Mohsen Golmohamadian, 2013). CBT is most appropriately used on clients with deductive thinking and deal with effects (Peorsan \& Wilson, 2009)

\section{Delinquency}

Delinquency among adolescents is considered a social problem and it is spreading extensively in many Malaysian communities. This phenomenon is impacting individual, families, and also the nation as a whole both in short and long term (Fauziah, 2005). Moreover the involvement of teenager in delinquency has also increased the fiscal and social cost which has in turn impacted the economic development of the nation (DeLisi, 2005; Foster, Jones \& Conduct Problems Prevention Research Group, 2006). This has endangered the condition of the family and the community (Jessor, 1998).

In this context, Santrock (2007) explained delinquent behavior as any behavior that goes against the rules and norms of a particular community (Jessor, 1998). In addition, it can also refer to a wider behavioral scope such as misbehaving at school or running away from home or even more serious behaviors such as theft. Capaldi and Shortt (2003) elaborate that most of the behavior that is considered delinquent is classified as abnormal action.

When teenagers engage in activities such as truancy, running away from home, arson, cruelty towards animal, 
theft, heightened quarrels, and so forth continuously for more than 6 months and if three or more of these activities take place before the age of 15 , psychiatric diagnostic members classify them as disturbed behaviors (Santrock, 2007). If teenagers engage in such activities to the point that they break the law then society will label them as delinquent (Santrock, 2007). Individuals who engage in this type of delinquent behavior are viewed as having more interest in satisfying their needs without considering the potential long-term consequences of such behavior (Wilson \& Daly, 2006).

Many studies haves considered the family's influences on delinquent behavior among youths (Cashwell \& Vacc, 1996; Fauziah, 2005; Glueck \& Glueck, 1950; Hirschi, 1969; Loeber \& Stouthamer-Loeber, 1998; Nye,1958; Patterson \& Stouthamer-Loeber, 1984; Rosen, 1985; Simmons, Wu Lin, Gordon \& Conger, 2000). In addition a number of studies have focused on the relationship between child and parent, family conflicts, and family pressure and how these may impact teenagers and the potential for engaging in delinquent behavior (Capaldi \& Shortt, 2003). Other factors contribute to the problem of teenage delinquency as well. For example, peer relationships have been found to play an important role in delinquency (Dolge, Coie, \& Lynam, 2006; Lauber, Marshall \& Mayers, 2005). Santrock (2007) found that coming from a low social economic status is a contributing factor toward teenage involvement in delinquency. Characteristics of the community are also correlated with causing delinquent behavior (Farrington, 2004; Kroneman, Loeber \& Hipwell, 2004; Sabol, Coulton \& Korbin, 2004).

In spite of the increase in the number of studies examining this issue, there is still a lack of in-depth studies which attempt to understand the teenagers' experience. In fact there are behavioral symptoms found during the development stage of teenagers which may contribute to delinquent behaviors. These might warrant a closer examination (Zaslow \& Takanishi, 1993).

Teenagers' experiences in what and how they perceive these issues need to be explored in depth. Their perception, behaviour, and feelings should be understood in order to unearth everything that lies within them. This is due to the fact that they are unable to express their thoughts and feelings verbally to adults (Graham \& Sontag, 2001). In this context, researchers attempt to utilize expressive art therapy as a media to understand the experiences of teenage delinquents. Through their artwork, most teenagers are capable to exhibit feelings and thoughts by expressing their feelings in certain symbolical features (Bennink, Gussak \& Skowan, 2003; Howard, 2001). These images through expressive arts could give a room for teenagers in crisis to mould imaginations to express and uphold those images naturally in their own creative measures (Graham \& Sontag, 2001).

Themes which are related to psychological issues in this study also support the findings by Rohany Nasir, Zainah Ahmad Khairuddin Rozainee \& Fatima Yusooff (2011) and Rohany Nasir, Zainah Ahmad Khairuddin Rozainee, \& Wan Shahrazad, (2011). These findings show us that most adolescents who are involved in delinquent behaviors are suffering from depression, thinking disorder, extreme pressure and can also cause trauma that motivates them to take unnecessary actions without considering the consequences. Thus, the experiences of these young adults shared in this study should be taken seriously. Their experiences which are related to psychological issues are some of the many factors that prevent the adolescents from resisting juvenile delinquent behaviors. This study was conducted to understand the elements of the creative relationship experiences during creative arts therapy in group counseling sessions.

\section{Methodology}

\subsection{Research Design}

A qualitative phenomenological research methods was employed in this study. Phenomenology refers to the study of the development of human consciousness and self-awareness as a preface to or a part of philosophy. This research method also gives importance to the meaning and the essence of the experience of each individual who is interviewed. An attempt is made to understand what is behind the delinquent behavior by better understanding life experience of teenagers involved. According to Gbirch (2007), phenomenology is an appropriate method to use when the researcher wants to understand the underlying meaning as well as the essence of a experience together with how the study participant understand it. This research approach involves the process of exploring the personal experiences of participants to ultimately, provide a more in-depth understanding of the phenomenon being studied (Gbirch, 2007).

\subsection{Participants and Setting}

Purposeful sampling were used to select the participants. In this sampling, the researcher purposely chose individuals who were involved in delinquent behavior with the goal of better understanding the participants' life experience in order to comprehend the phenomenon of delinquent behavior (Creswell, 2008). This technique was 
used to identify individuals and cases rich in research information relevant to this phenomenon. Participant in this research were chosen based on the scrutiny and the purpose of this study. Those participants who were selected had direct experience in relation to the phenomenon under study that is those who were involved in delinquent behavior.

To determine the number of research participant, Merriam (2002), stated that there is no specific number of participants required for qualitative research. According to Marohaini Yusoff (2004), a small number of participants is sufficient because the main focus for qualitative research is to obtain input that can provide a holistic and meaningful picture regarding the phenomenon that is being researched. Similarly, Creswell (1998), expounded that there is no minimum number of participant required for ongoing qualitative research using a phenomenological approach. Others have proposed that a certain number of participant might produce the best results. Dukes (1984) proposed 3 to 10 subjects whereas Riemen (1986) proposed 10 subjects. Ultimately, what is important is that the number of subjects participating in the study is enough to depict the meaning and experience of the individuals who have lived the phenomenon being studied (Creswell, 1998).

The participants in this study volunteered to be research participants. At the onset of the research, there were 10 subjects who were involved and participated in the study. At the end of this research, the researcher only choose 7 subjects to be fully analyzed and presented in the final results. This was because 3 of 10 research participants were not able to commit fully throughout the research period for various reasons. Two of them could not write in their diaries as they were unable to read and write. One of them was ill for most duration of the study and, as a result, unable to fully participate. As such, 7 teenage girls who were involved in delinquency and detained at a correctional center participated in this research. Their ages were between 16 and 18 years old. Participants were given consent forms as a mark of acceptance. The research subject were given index-number assignment as follow: S01, S02, S03, S04, S05, S06, and S07. This technique was used to ensure the anonymity of the study participants.

The table below shows research participants' background

Table 1. Participants' background

\begin{tabular}{|c|c|c|c|c|c|c|c|}
\hline Particular & S01 & S02 & $\mathrm{S} 03$ & S04 & S05 & S06 & S07 \\
\hline Age & 18 & 18 & 18 & 17 & 17 & 16 & 18 \\
\hline Case & $\begin{array}{l}\text { Pregnancy } \\
\text { and } \\
\text { uncontrolled } \\
\text { behaviour }\end{array}$ & $\begin{array}{l}\text { Uncontrolled } \\
\text { behaviour }\end{array}$ & $\begin{array}{l}\text { Uncontrolled } \\
\text { behaviour }\end{array}$ & $\begin{array}{l}\text { Uncontrolled } \\
\text { behaviour }\end{array}$ & $\begin{array}{l}\text { Pregnancy } \\
\text { and } \\
\text { uncontrolled } \\
\text { behaviour }\end{array}$ & $\begin{array}{l}\text { Uncontrolled } \\
\text { behaviour }\end{array}$ & $\begin{array}{l}\text { Uncontrolled } \\
\text { behaviour }\end{array}$ \\
\hline $\begin{array}{l}\text { Period of } \\
\text { detention }\end{array}$ & 3 years & 3 years & 3 years & 3 years & 3 years & 2 years & 3 years \\
\hline $\begin{array}{l}\text { Date of } \\
\text { detention }\end{array}$ & $9 / 1 / 2008$ & $30 / 4 / 2008$ & $31 / 1 / 2009$ & $30 / 8 / 2010$ & $30 / 1 / 2009$ & $5 / 11 / 2009$ & $7 / 5 / 2009$ \\
\hline
\end{tabular}

\subsection{Data Collection}

Multiple source triangulation that is in-depth interview, observation and document analysis was used to collect the data. Interviews based on phenomenological approach were conducted. A series of in-depth interviews were conducted with the goal of learning about the participants' lives and obtaining information based on assumptions grounded in phenomenology. In this approach, the researcher used open-ended questions to encourage the participants to openly share. The researcher constructed and explored participants' responses to the questions.

As this study utilized phenomenological approach, the interview processed was based on the interview model developed by Seidman (1998). According to Seidman, an in-depth phenomenological interviews include a series of three separate interviews. These three interview are completed to enable interviewer and the subjects to understand the mystery of the experience and to place the experience into context (Seidman, 1998). The first series of interviews provides the context for the experiences of the subjects. The second series of interviews allows the participants to reconstruct the details of their experiences regarding the phenomenon being studied. Whereas, the third series interviews encourages the subject to recall the meaning and essence of their 
experiences (Seidman, 1998).

Each interview in this study took between 90 and 120 minutes. The interview process took place in three phases. The first phase of interviewing was conducted after every subject had completed sessions (1st, 2nd, and 3rd sessions) of group counseling. In this first phase, the focus of the interview was based on the life history of the subject. The second phase of the interview was carried out after every subject had completed three more sessions (4th, 5th, and 6th sessions) of group counseling. In this second phase of interviewing the researcher focuses on the personal experiences of the subject. This was followed by the third phase of interview process. This final interview was conducted after all the subjects had undergone two more sessions (7th and 8th sessions) of group counseling. The focus of this interview was meant to reflect the meaning of the subjects' experiences. The interviews in every session were recorded and then transcribed in details to enable the researcher to obtain clear and in-depth information for the phenomenon under study. The interview protocol was prepared before starting the interview process in every phase of interviewing.

The second sources of data in this study was verbal and non-verbal observation of each subject in the group counseling sessions. Observing the participant is a technique to obtain the real picture of the phenomenon under study (Crewell, 2003 ; Silverman, 2002). This technique is a process to gain direct information from the original source that is, the study participant. The participants' responses, dialogues, and movements are observed in each group counseling sessions.

Direct observation enables the researcher to understand the possible context of the phenomenon being studied. Observing subjects as they engage in expressive art therapy can bring to light additional information about past experiences and how these experiences may be contributing to delinquent behavior in the present. Every observation session would raise questions for the researcher which were then recorded and used as questions in the interview sessions. For each session the researcher took field notes following specific observation protocol that was defined at the start of the study. These field notes are collected as raw data in relation to the phenomenon being studied. In addition, researcher's comments were recorded as well; for example, any thoughts and feeling that may have crossed the researcher's mind would be noted. Participants were observed using an expressive art therapy during 8 group sessions over a 4-month period with each session lasting 2 or 3 hours.

The third and final sources of data came from analyzing the text submitted by each participant. Participants were asked to write a journal or prepare a diary which expressed their life story. This diary was completed by each participant by using art materials provided throughout the study. Participant were asked to describe experiences from their past as well as their feelings and responses to the group counseling sessions. The written diary was an alternative avenue for the subject to express things that they may not have felt comfortable sharing in the group sessions or during the one-on-one interviews.

\subsection{Validity and Reliability}

In this study, various approaches were taken to ensure the validity and reliability of the research results. To ensure the validity and reliability of the research, several processes were conducted; (a) data triangulation, (b) prolonged engagement, (c) peer review and (d) audit trail.

\subsubsection{Triangulation}

Patton (2002) and Merriam (2001) identified four types of triangulation that can be used in a study. They are method triangulation, data triangulation, researcher triangulation and theory triangulation. This study used data triangulation which is the use of multiple source of data in order to increase the validity of the study. The multiple sources of data for this study were the tree interviews, observation from 8 group counseling session and analysis of the personal journals from each participant. This data triangulation or collection of multiple sources of data was applied throughout the study to ensure the validity and reliability the result.

\subsubsection{Prolonged Engagement}

The data collection in this study was conducted for a prolonged period of time a prolonged engagement with the study spanning 4 months. This step was taken to allow sufficient time to collect the variety of data (via interview, observation, and document analysis). It was decided that 4 months' time were reasonable for participants to feel comfortable enough to share their life experiences. In addition, it was also important for the researcher to have sufficient time (prolonged engagement) in the field of study. Ensuring that the researcher spent a sufficient amount of time (prolonged engagement) in the field was also an important factor to ensure that the amount and types of data collected were adequate (Patton, 2002). It is necessary for researcher to spend enough time in the field so that they can see the patterns in the data which, in turn, will allow them to better understand the phenomenon being studied (Patton, 2002). This is important to ensure the reliability of the data. 


\subsubsection{Peer Review}

Another category that was identified by Merriam (2001) to validate research finding is peer review. Peer review refers to a method of ensuring that all data collected is reviewed by one's peers who will then provide feedback and comment to the researchers. At each stage of data collection, the result were reviewed by peers, other researchers as well as the study's research supervisor. Feedback and comments from these reviewers were thoroughly discussed and integrated into the data analysis as needed. Submission and interpretation of data for scrutiny by other researcher, peers, and the research supervisor (all of whom were well-informed in the field of study) helped immensely in the interpretation and final documentation of the research findings.

\subsubsection{Audit Trail}

Another method for ensuring validity that was used in this study was using an audit trail. Lincon and Guba (1985) stated that an audit trail was an important aspect to be considered by any qualitative researcher. Lincon and Guba felt that an audit trail was an important step in ensuring the trustworthiness of the data collected. Othman Lebar (2006) elaborated that an audit trail was a way for researcher to document every step taken throughout the study. This process involves a detailed documenting of everything related to the research process from beginning to end. The audit trail should include every decision that was made and why, how participants were selected, how the participants' anonymity was protected, how activities were selected and carried out, the chronology of data collection, how the data was analyzed, how the results were peer reviewed and so forth. In this study, the researcher used a journal and a log book as a venue to record every step and research process implemented. Every process was recorded, filed and transcribed. Data was saved in a computer for any future audit trail. Likewise, the presentation of writing and reporting of this research were also documented. All the data and findings were carefully cited. An index was created for every type of data collection. The source for all results and data findings were cited according to a code or index. This index consisted of a series of numbers which identified where the data came from.

The index numbers encoded important details about the origin of each piece of data. The index number indicated various factors about the origin of the data such as: (a) participant number (b) form of data collected, verbal/interview or written/diary (c) the meaning it had for the subject, meaning unit, and the (d) date collected. For example, the index S01: MU120/11 meant that is was obtained from Subject 01 (S01), it involved Meaning Unit 120 (MU120) and it was originally recorded in S01's Interview 1 (I1). As a result of a careful analysis of both the participant interviews and their written diaries, the researcher developed themes that were found to be common to the majority of the participants. In relation to the document analysis or the analysis of the participants' diaries, all themes where numbered and mapped to specific pages within the participants diaries . example "S02: MU089/12; Pg013, Pg021, Pg038/D" meant that meaning Unit 089 (originally talked about in S02's Interview \#2) expressed by Subject 02 (S02) on pages (Pg) 013, 021, 038 of her diary. For the observation of data "S04: (050110)/12-19/01" meant that the statement was taken from Subject 04 (S04) on 05.01.2010 (050110) between lines 12-19 as observation $1(01)$. The indexing of every finding was done to enable the researcher and other reader to trace everything back to its original data point. By implementing this detailed index-numbering system (another dimension of the audit trail) the validity and reliability of the data in this study was enhanced.

\subsection{Data Analysis}

Data analysis was based upon the steps recommended by Giorgi and Giorgi (2003). These steps included sense of the whole, discrimination of the meaning units, initial transformation of the meaning unit, and psychological structure.

The first step is to find the overall meaning. The researcher begins the process of analysis by reading the transcripts of all the subjects several times in order to understand the overall meaning. This step enables researcher to begin understanding the life experiences of the teenagers as well as their experiences during group counseling session using expressive art therapy. Reading transcripts holistically helps the researcher to be prepared for the second step which is discrimination of the meaning units. Since the text cannot be interpreted as a whole, the verbatim transcripts of the subjects' interviews are broken down into smaller units that are more meaningful and understandable.

The third step is the early transfer of meaning units. The first phase of this transformation and transfer process is to highlight the meaning that appears in every meaning unit. This is done by using parallel language to the one used by the research subjects. The second phase of this transformation is to translate the life experiences of the subject into a language that contains psychological meaning. 
The next step is to determine the psychological structure of the individual. This phase in the analysis requires the combination of all the meaning unit found into comprehensive and complete description which describe the experiences of the individual.

This is done in order to determine the general psychological structure of each subject. In this last phase of the analysis, the researcher tries to move from the specific life experience of one individual to a general description about these experiences for all the teenagers involved in the study. The transformation process is the reiterative process of moving from the specific subjective experience of one participant to the general structure of the phenomenon being studied. The last step is the emergence of the theme.

\section{Results}

The results showed that there were some psychological issues that had emerged in sharing and expression sessions by all subjects in the study. The study participants shared their feelings and consequently some themes were identified as the research findings; which are hatred, anger and revenge, frustration and sadness, rebellious, begging for affection, looking for happiness and enjoyment of life, low self-esteem and issues on traumatic and emotional disorders that have been experienced in their lives as depicted in Table 2.

Table 2. Themes

\begin{tabular}{|c|c|c|c|c|c|c|c|}
\hline \multirow[t]{2}{*}{ THEME } & \multicolumn{7}{|c|}{ SUBJECT } \\
\hline & S01 & S02 & S03 & S04 & S05 & S06 & S07 \\
\hline Hatred, Anger and Revenge & $\sqrt{ }$ & $\sqrt{ }$ & $\sqrt{ }$ & $\sqrt{ }$ & $\sqrt{ }$ & $\sqrt{ }$ & $\sqrt{ }$ \\
\hline Frustration and Sadness & $\sqrt{ }$ & $\sqrt{ }$ & $\sqrt{ }$ & $\sqrt{ }$ & $\sqrt{ }$ & $\sqrt{ }$ & $\sqrt{ }$ \\
\hline Rebellious & $\sqrt{ }$ & & & & & $\sqrt{ }$ & \\
\hline Begging for affection & $\sqrt{ }$ & $\sqrt{ }$ & & $\sqrt{ }$ & $\sqrt{ }$ & $\sqrt{ }$ & $\sqrt{ }$ \\
\hline Looking for happiness and enjoyment of life & $\sqrt{ }$ & $\sqrt{ }$ & $\sqrt{ }$ & $\sqrt{ }$ & $\sqrt{ }$ & $\sqrt{ }$ & $\sqrt{ }$ \\
\hline Low self-esteem & $\sqrt{ }$ & $\sqrt{ }$ & $\sqrt{ }$ & $\sqrt{ }$ & $\sqrt{ }$ & $\sqrt{ }$ & $\sqrt{ }$ \\
\hline Trauma and Emotional Disorder & $\sqrt{ }$ & $\sqrt{ }$ & $\sqrt{ }$ & $\sqrt{ }$ & $\sqrt{ }$ & $\sqrt{ }$ & $\sqrt{ }$ \\
\hline
\end{tabular}

\subsection{Theme 1: Hatred, Anger and Revenge}

This issue was shared by all subjects. They expressed feelings of hatred, revenge and anger which had been stored in their hearts for significant people who had ruined their lives. S01 expressed hatred, revenge and anger against her father. His fierce and brutal attitude towards her made her resent him [S01: UM048/T1]. Similarly, she had the feelings of hatred and revenge against her boyfriend. His act of leaving her while she was pregnant with their illegitimate child, made her continue to keep those feelings [S01: UM188/T1].

"I really hate the people whom I thought significant in my live but they turned out to be evil" (SO1)

"I can never forget until the day I die. I will never forget. I can still remember...the guy was a monster..." (SO1)

S02 also expressed the feelings of hatred, revenge and anger towards her father. His actions which include harassment, molestation and several attempts of raping her had made S02 to continue having these feelings.

"He is not my father... he is a traitor... I suffer because of him..." (S02)

S03 also expressed the feelings of hatred, revenge and anger against her mother [S03: UM027/T1]. Her mother's act that separated her with her foster mother whom has cared for her since she was small caused dissatisfaction and anger towards her mother [S03: UM022/T1, UM026/T1]. S03 also stated that she could not forgive her mother who selfishly turned her into becoming a prostitute for her mother's own good [S03: UM049/T1, UM141/T2].

"I can never care for her...I hate her...she will know someday who I am .... she will get it.." (S03)

S03 in addition expressed her feelings of hatred and vengeance against the men who raped her [S03: UM142/T2]. Figure 1 shows S03's creativity arts. 


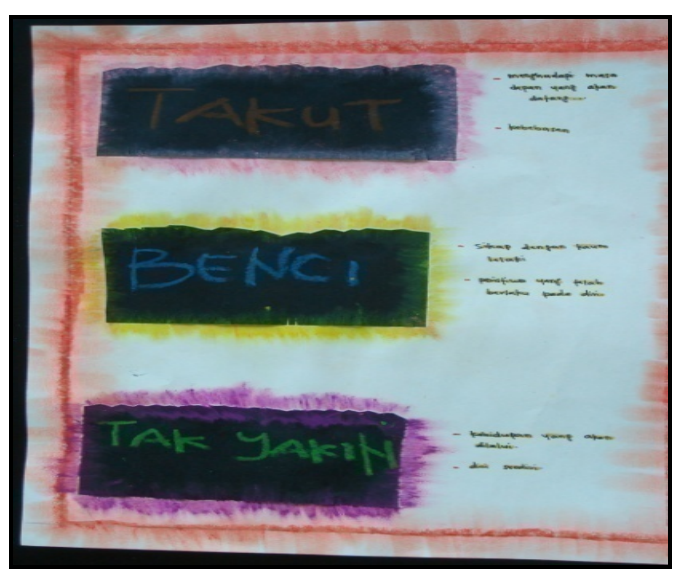

Figure 1. S03's creativity arts

For S04, she expressed her feelings of hatred, revenge and anger towards her father due to his hot-tempered attitude which always ended with hitting her and her mother [S04: UM125/T2, UM140/T2].

"He is never a father to me...just by looking at his face makes me hate him so much..I don't like it... who cares who he is..." (S04)

The same feeling was also shared by S05. She expressed the feelings of hatred and anger against the man who was responsible for making her pregnant [S05: UM072/T1]. She also expressed her feelings of hatred, resentment and anger towards her stepmother. Her stepmother's torture on her and her other siblings made her so angry and bitter against her stepmother [S05: UM105/T1].

"I can never accept her...she was an egotistical person...I really hate her..." (S05)

S06 also expressed her feelings of hatred, anger and revenge towards her foster mother [S06: UM080/T1, UM083/T1, UM165/T2]. She stated that her foster mother was a cruel mother.

"If I ever meet her, I would never talk to her...I hate her so much ...she made me suffer..." (S06)

For S07, she hated both her mother and father [S07: UM019/T1]. She claimed that the feeling of hatred was more towards her mother than her father. This is due to the fact that even though her father never paid attention and cared for her but at least he never beat her severely as her mother [S07: UM020/T1]. S07 also stated that she had never admitted her as a mother; in fact she resented her mother and will not accept and forgive her mother.

\subsection{Theme 2: Frustration and Sadness}

All the subjects expressed their feelings of frustration and sadness based on the experiences in their lives. Various ordeals haven taken place in S01's life that made her so upset. Her family was often in turmoil, lack of love among them, faced poverty and other challenges of life. Things became worse when S01 was raped at the age of 11 years old which made S01 blame her destiny and she was totally disappointed with her life [S01: UM091/T1]. The frustration drove S01 to live away from the true and guided path [S01: UM092/T1, UM102/T1]. S01 finally was involved with various social illnesses that continued to bring her negative influences [S01: UM104/T1].

"I am very frustrated...there's a lot that I feel inside...sadness...it feels like there's no light in my life..." (SO1)

In the meantime, $\mathrm{S} 02$ was disappointed and expressed her sadness on her father's attitude who was a drug addict [S02: UM148/T1]. S02 also stated that she was unhappy and disappointed when recalling her experience when she was despised and neglected by his father's side of the family.

"My father is an addict...every day I saw him taking drugs...it is sad watching your father like that...I can no longer shed anymore tears...I've been feeling sad all my life..." (S02)

S03 also expressed her frustrations and sadness when she reminisced her experience of being separated from her foster mother who has raised her by her biological mother [S03:UM018/T1, UM021/T1, UM025/T1, UM033/T1, UM053/T1]. Bitter experiences and events that occurred in her life made S03 felt so frustrated [S03: $\mathrm{UM} 140 / \mathrm{T} 2]$. 
"I don't know how to share my feelings...it feels like there's no hope anymore...my life is awful...it is sad when I think about it all..." (SO3)

S04 then noted that her life was often in despair and grief. Her cruel father's attitude and behavior who often looked for her faults and always believed his second wife more as compared to her mother resulted in making S04 feeling so disappointed with her life [S04: UM015/T1, UM052/T1, UM100/T1]. S04 also confided that she always cried when she saw her mother often beaten by her father [S04: UM023/T1]. The same feeling was described by S05. S05 also stated that she was frustrated with the life that she went through before [S05:UM121/T1, UM158/T2, UM161/T2].

For S06, disappointments in life have caused her to continue moving farther away and she moved on without direction. She was so frustrated with her life as she has never been defended by anyone. It was a huge test for her to continue life with her foster mother's attitudes who could never accept her as who she is [S06: UM105/T1, UM127/T2]. Further disappointment and sadness were experienced when her own biological mother could not take her in [S06: UM110/T1, UM120/T1, UM130/T2]. These sentiments were reflected by the S06's creativity art in Figure 2.

"I'll take my sadness with me...there's no happiness in my life...other people look so happy...but I always cry..." (S06)

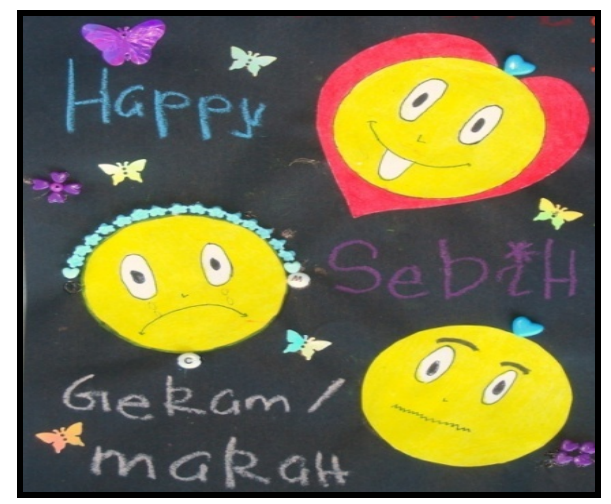

Figure 2. S06's creativity art

S07 felt the same way. She was very upset with her mother's attitude of never accepting her as her own daughter [S07: UM010/T1, UM022/T1]. She also expressed her thoughts that life is full of disappointment and sorrow [S07:UM118/T2].

\subsection{Theme 3: Rebellious}

There are also subjects that stated that they rebelled when they could no longer deal with the challenges in their lives. For S04, when she was feeling depressed and rebellious, she would usually go against her foster mother and ran away from home [S04: UM145/T2]. The feelings experienced by S04 were reflected in her creativity art in Figure 3.

"If I was not satisfied and didn't like it, I would rebel and I did whatever I like...I stayed out...I came home late night..." (S04)

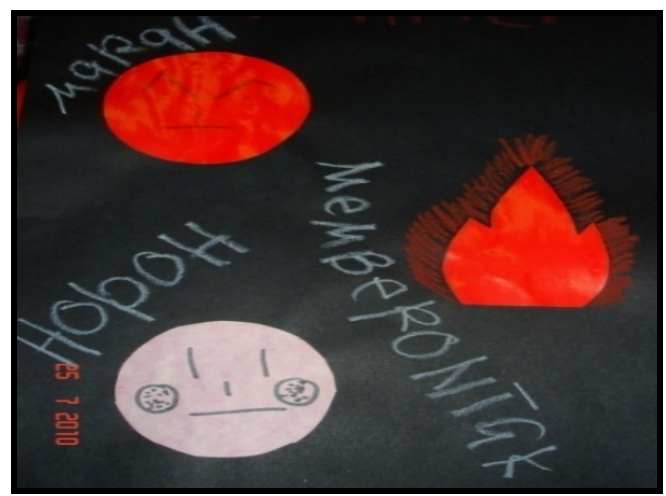

Figure 3. S04's creativity art 
S01 stated that she felt challenged and revolted and consequently she did things that were not supposed to happen, which ended up damaging herself [S01: UM058/T1, UM100/T1, UM101/T1].

"Other people would never know how I feel...I did all these...because I was not satisfied...I will never do or listen to whatever my mother says...I will do whatever I feel like doing..." (S01)

\subsection{Theme 4: Begging for Affection}

Most study subjects also indicated that they never got the love from their family. They eventually begged for affection from others. S01 expressed her feelings of needing attention. The attention given by her boyfriend made her feel loved and finally she was willing to give herself away to him for the sake of begging for affection [S01: UM225/T2, UM233/T2].

"My boyfriend could shower his love on me...I felt there was someone who cared for me...I didn't feel lonely..." (S01)

S02 had the same encounter. She also stated that she never felt love from her family [S02: UM170/T2, UM273/T2]. Figure 4 shows the creativity art made by S02.

"I never felt love and affection...I was never loved by my family...I ran away..." (SO2)

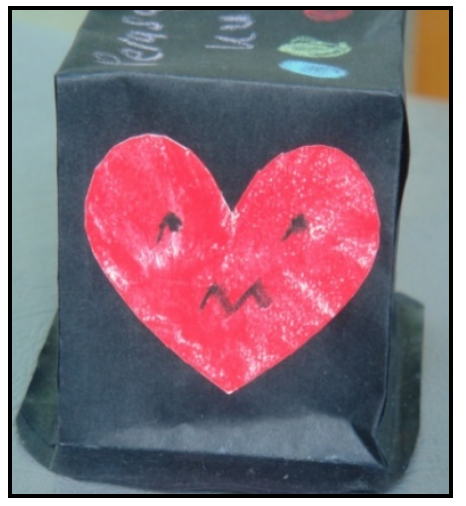

Figure 4. S02's creativity art

Meantime, S04 also expressed her thirst for love and affection. S04 described how she needed love and attention from her family. S04 shared her experience of ruining her pride and honour by giving in to her boyfriend's lust who claimed that he loved her [S04:UM027/T1, UM049/T1].

"I really wanted my parents' love and affection...nobody loved me...but when I finally met my boyfriend, I felt love... he really loved me..." (S04)

Similar circumstances and experiences were shared by S05. She recounted how she was willing to submit herself to her boyfriend for the sake of love. Eventually, she was left alone. Love that she sought ended with the feeling of regret and despair [S05: UM106/T1].

"I loved my boyfriend... he took care of me...I would give everything to him ..." (S05)

S06 also shared her experience which she also was hungry for love and affection. S06 changed her personality in order to be a man and begged for affection from her girlfriend. S06 claimed to be very happy to be a man and was able to share love with her girlfriend [S06: UM 071/T1, UM125/T1, UM184/T2].

"We shared mutual love...we could not be separated..she was a woman that understood me..." (SO6)

S07 also expressed her feelings of needing love from her own mother [S07: UM063/T1, UM084/T1, UM114/T2]. S07 hoped that she will get the attention and love that she really needed someday.

"Hopefully my parents will take me back and still love me..maybe they were busy before and that made me think they didn't love me.." (S07)

\subsection{Theme 5: Looking for Happiness, Satisfaction and Enjoyment of Life}

In this context, all subjects shared their stories and stated that they felt pressured by the pain that they 
experienced in order to find happiness, satisfaction and pleasure by getting involved in juvenile delinquent behaviors. They did it because they wanted to get rid of all the stress that they had. S01 stated that she had sex just to have fun in her life [S01: UM223/T2]. She also took banned substances such as smoking, drinking alcohol, ecstasy pills and socialized freely in order to obtain self-satisfaction. S01 believed that she lived in her own world when taking prohibited substances.

"I was ecstatic when I could sleep together with my boyfriend...feel happy when there was someone who cared for me...my boyfriend and I were like husband and wife...together we took pills... we lived in our own world...it felt like total life bliss" (SO1)

S03 shared her story and said that alcohol, cigarettes, ecstasy pills and sex could make her forget all the dark events that often disturbed and haunted her. She felt happy by doing those delinquent behaviours [S03: UM109/T1, UM137/T2, UM138/T2].

"When I had sex, I could forget my problems in life for awhile...sometimes I took pills...drank alchohols with friends who have same problem like me..." (S03)

For S04, she felt that her friends can give pleasure and happiness in her life [S04: UM078/T1]. She also stated that she got along with her friends and was involved with social activities simply to release all the stress she had from her life's experiences [S04: UM158/T2, UM159/T2].

"Usually when I was with my friends, I was happy..ecstatic...we would hang out..racing together...sometimes I took the pills my friends gave me...it was fun.. " (SO4)

The feeling was as well shared by S05.For S05, she felt excited with great satisfaction when getting a free ride on the motorcycle with her boyfriend. Her life was claimed to be happy and calm when she could be with her friends [S05: UM095/T1, UM097/T1, UM175/T2].

"When I was riding the motorcycle with my boyfriend...I felt like the world was mine...it was fun.. and I was satisfied..I felt like flying..." (S05)

S06 also stated that she would take pills, cigarettes and alcohol to have serene mind and life satisfaction [S06: UM073/T1, UM122/T1]. For her, promiscuity and having experiences in negative activities could bring happiness and enjoyment of life that were not found in her life before [S06: UM231/T3].

"The pills that I took...those were ecstasy that we usually share with friends...I also smoke cigarettes...drinking alchohol also gave me joy...we were satisfied and overjoyed...felt free hanging out with friends" (SO6)

As for S07, the sustained pressure boiling inside has led her to have fun with her friends [S07:UM108/T2].S07's happiness, satisfaction and enjoyment in life were described in figure 5.

"I would go out with my friends when I was stressed out and pressured...when I hang out with them..I feel happy..." (S07)

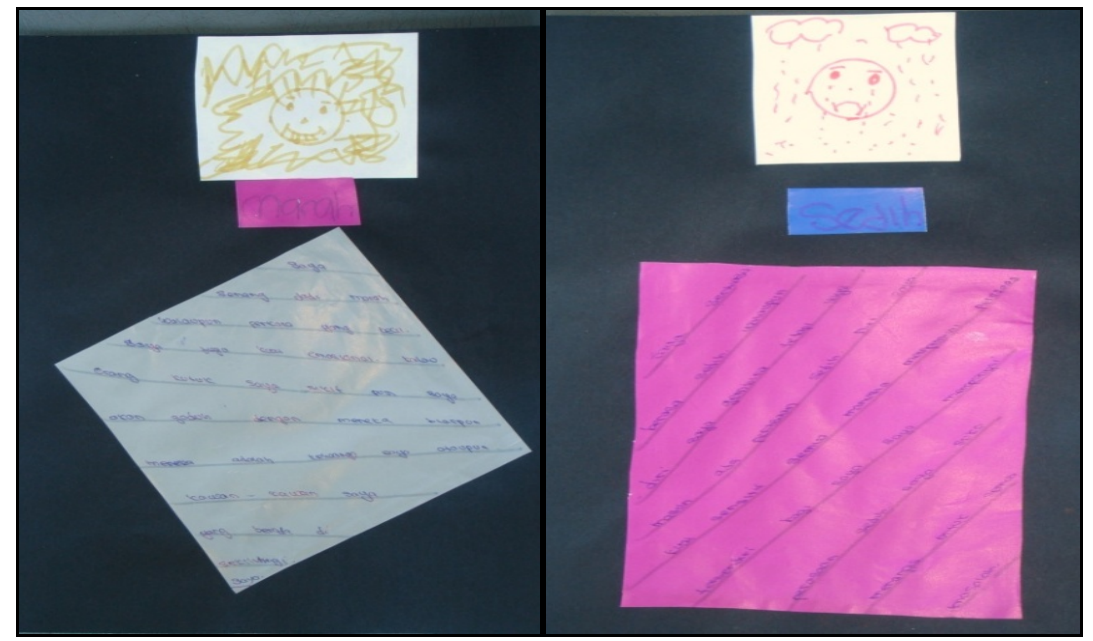

Figure 5. S07's creativity art 


\subsection{Theme 6: Low Self-Esteem}

All seven subjects stated that they felt insulted and regarded themselves as not having self-esteem. All of them expressed their feelings and shared stories that they have been having low self-esteem for a long time. The feeling has prompted them to continue getting involved with delinquent behaviors. S01 describes her sickened feeling of herself after she was raped. Since that unfortunate event, she felt that she was nothing and has lost any meaning of life [S01: UM085/T1].

"Now I feel that I am disgusting and dirty...at first, I was having fun..." (S01)

S02 also experienced the same feelings. She felt humiliated when his father's side of the family often insulted her by using abusive words against her and her mother [S02: UM243/T2, UM246/T2].

"I feel so low and disgusted with myself...my family from my father's side always insulted me...I think I am useless..." (SO2)

S03 also felt that she has no self-esteem, despicable, was no longer sacred and useless and therefore she was then engaged in negative activities [S03: UM108/T1, UM110/T1]. She also felt that she was so disgusting and despicable in the eyes of society and saw no point in making amends in her life [S03:UM124/T2, UM143/T2].

"I am dirty...extremely dirty..I feel that I am useless..even if I become a good person, other people will not accept me...it is better if I just continue hanging out with my friends...I can take pills..I can drink alchohol... having fun..." (SO3)

S04 experienced the same circumstance. Insults hurled by his father always made S04 felt that she was useless and insignificant [S04: UM137/T2].

"My father didn't like me... he insulted me...I am a worthless daughter..." (S04)

S05 equally expressed that she was always detested and seen as worthless by the family and society. She also felt that her fate was so unfortunate compared to others [S05: UM116/T1, UM181/T2]. S05's self-appreciation was illustrated in Figure 6.

"Everybody insulted me...I am useless...even my family won't accept me...I am not like other people..I bring misfortunes..." (S05)

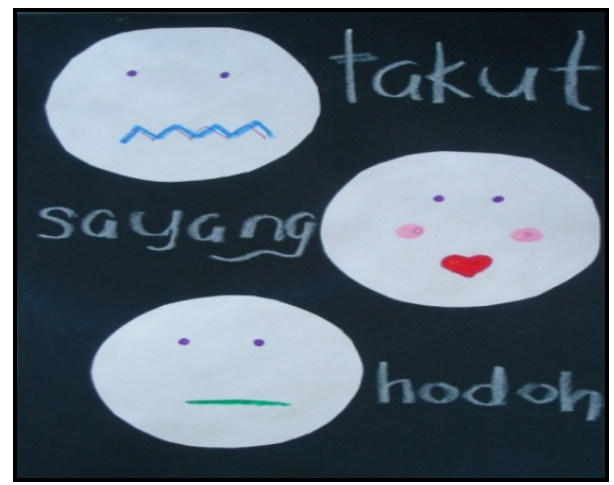

Figure 6. S05's creativity art

Feelings of shame and humiliation have made S06 felt her life was meaningless in this world [S06: UM128/T2]. The feelings that S06 had in her made her want to kill herself [S06: UM131/T2]. She also felt that she was useless and she was totally alone [S06: UM194/T2].

"I am filthy...I am useless...I don't know how my future is going to be...there is no meaning in my life..." (SO6)

S07 also narrated and shared her feelings that her life was just empty and she had no place and no one to confide in and in due course, she felt she was worthless. She also felt inferior and intimidated looking at the scars on her body after being hit by her mother [S07:UM043/T1, UM106/T2].

\subsection{Theme 7: Trauma and Emotional Disorder}

Trauma and emotional disorder issues were often told and expressed by all the subjects. They expressed that stress and hardships in life made them experience frequent fear, phobia and emotional disturbance. Their emotions were unstable and made them feel depressed that they release their feelings by doing improper actions. 
In this context, S01 stated that she used to feel the trauma, phobias and fears when recalling her father brutal and fierce attitude and her mother's acts of beating her [S01: UM024/T1, UM070/T1, UM202/T2]. S01 mentioned her resistance of returning home for fear of being beaten by her mother [S01: UM071/T1]. Figure 7 shows S01's creativity art depicting her emotion.

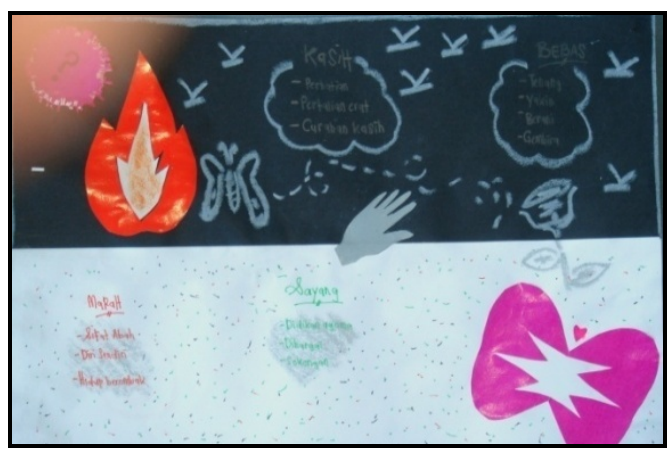

Figure 7. S01's creativity art

"I was scared looking at my father's face...whenever I think of him, I am scared...I turn psychotic...suddenly I feel like I lose myself...the same goes with my mother...she loved scolding me..."(S01)

Similarly, S01 was always in fear, sadness and emotionally disturbed, forcing her to find pleasure elsewhere when she recalled being raped at the age of 11 [S01: UM210/T2]. For S02, the agony that she faced having to deal with her father's irresponsible attitude made her emotionally distracted. The possibility of bumping into her father has threatened her peaceful life as she has been having the feelings of sadness, fear and phobia [S02:UM172/T2, UM174/T2].

S03 suffered from depression and was terribly pressured. The unfortunate occurrences of being turned into a prostitute and mass raped have haunted and plagued her life [S03: UM069/T1, UM070/T1, UM093/T1].

"The moment when I was raped was an event that scared me...I couldn't think...I feel like I want to kill those men..it was horrible and I suffered...I was treated like an animal..."(SO3)

As for S04, she would run amok and often suffered from depression and emotional disorders. She would cry loudly when she could and would throw away her belongings to her satisfaction. S04 also confided that she often had nightmares where in her dreams, she was beaten by her father [S04: UM050/T1, UM051/T1, UM117/T1, UM144/T2].

"That is why I always throw a tantrum...I can't really think about my life...I feel like crying as loud as possible..." (S04)

S05 narrated that she often suffered out of fear having to deal with her stepmother. The fear she felt made her not to return home and ran away [S05: UM013/T1, UM037/T1]. For S06, the experiences of being molested and almost raped by an Indian friend from school at the age of 9 have left a permanent trauma in her life and it brought to identity transformation into becoming a man [S06:UM076/T1, UM151/T2, UM163/T2, UM195/T2].

"I want to be a man...I want to be as strong as a man...as a woman, we will be suppressed ... raped ... and so many more..." (S06)

S07 also confided that she suffered severe emotional disorder that often led to emotional instability [S07: UM107/T2]. The stress-induced life was due to the fact that she was always severely beaten by her mother and this often caused S07 to experience disturbances such as nightmares [S07: UM125/T2]. Emotional disorders also caused her to go berserk and suffer from sudden depression.

"I dream a lot...terrifying nightmares...my mother was an evil...I really hate her..." (S07)

\section{Discussion}

The findings show that the use of Expressive Arts Therapy is an intervention that can be taken to assist counselors in addressing issues that are related to the phenomenon of juvenile delinquency and other issues affecting adolescents. The usage also shows a way that they can interact with a phenomenological approach undertaken for this study in understanding the subjects' life experiences wholly and holistically. 
The results of the effectiveness of the sessions can be seen when the participants are able to achieve the level of catharsis where they can express what is experienced in life without obstacles. This shows that participants in this group are more comfortable with the environment and communication sessions conducted by the counselors psychologically. Participants can also tell a story and discover their own true feelings after being explored by counselors in session. The findings of this study coincide with the views of Deaver (2002) and Fin (2003) that claimed art is a potential healing and catharsis tool.

Counseling is a process to help clients or individuals make adjustments in personal, social and emotion in order to function better in the environment. In the context of this study, as a relatively new approach in Malaysia, Expressive Arts Therapy is used to test its effectiveness for youths who have been involved with juvenile delinquency. Expressive Arts Therapy approach has been used in a variety of issues and problems, especially in group counseling (Testa \& McCarthy, 2004).

The implementation of this study has given an overview of the paradigm shift in the diversification of therapeutic approaches in order to improve the professionalism of counseling field's knowledge especially to counselors. According to Hartz \& Thick (2005), this approach can bring awareness and a deeper self-acceptance. The findings also have implications for the local community. The findings of this psychological issues show that there are still much more loopholes and shortcomings existing in the community that contribute to delinquency symptoms. It is hoped to bring awareness to the people of the community in overall.

Although many studies have been conducted before, (Wadeson \& Writz, 2005; Hanes, 2000; Robertson, 2001) on the use of Expressive Arts Therapy in rehabilitating individuals who face a variety of contextual problems, but most researches were conducted in the Western community. It is high time that the reviews of the findings of previous studies are observed critically with the intention that they can be a booster and guidance to counseling practitioners in Malaysia. It is surely an approach that can be highlighted. Results of previous studies show that the use of Expressive Arts Therapy is a medium that can be used by the counselors in helping clients by providing healing, self-awareness and insight.

There are several issues related to the psychological development that have been disturbing the young adults' emotional stability in this study. The study found that their experiences with dysfunctional family dynamics, their experience of physical abuse, emotional and sexual abuse and other experiences as have been portrayed in previous chapters have left a deep impression on them. A string of such ill-fated experiences occurred in earlier phase of their lives, and they have dealt with psychological issues such as hatred, anger, revenge, frustration and sadness. Thus, they revolted to delinquent behaviors in order to express frustration experienced by them. This finding supports the study by Rahil, Manial and Habibah (2005), who described that depression, stress and psychological issues such as those found in this study, are the psychological issues that can lead to the teenagers' imprudent judgment and sanity.

Understanding their life experiences has given an impression to the authors that these subjects' lives are full of catastrophic occurrences. They have to beg for love and affection from their peers and boyfriends who are considered as their spouses. Due to that, they give up everything that they have until they are trapped by their peers' deceptions and intrigued with their boyfriend's empty promises. Their involvement in delinquent behaviors is also another means for them to find happiness and enjoyment of life which they never experience in their families. Similarly, McCord, Widom, \& Crowell (2003) found out that those adolescents with emotional disorders have a high tendency to get involved with unhealthy and reprehensible activities as drug use.

The study subjects who are involved with delinquent behaviors are associated with low self-esteem. Various events that have been bitterly experienced in their lives make them feel that they are no longer valuable and useful. Some of them see themselves as community disposal. These perceptions have provoked them into continuously getting involved with unseemly activities such as delinquent behaviors. In addition, their lives are full of trauma and emotional disorder. Their previous life experiences affect their emotional stability. The pressures and life demands faced by them will also have caused them not to think wisely and therefore they take the easy way out by taking prohibited substances such as alcohol, smoking, ecstasy pills, hanging out, skipping school and get involved with illegal racing. This is consistent with the study conducted by Huizinga, Loeber, Thornberry, \& Cothern (2000) which shows that there is a significant relationship between mental health problems and delinquent behaviors.

The disturbances have also awakened their feelings of being pressured and depressed until they take actions beyond their control such as attempting suicide. The findings in this study are supported by research (Rahil et al., 2005) which describes that depression, stress and psychological issues such as those found in this study are the psychological issues that can lead to the teenagers' imprudent judgment and sanity. They end up taking a short 
road and simply think of committing suicidal acts (Rahil et al., 2005). Another study also found that depression, a result of psychological disorders is one of the risks for teenagers get involved in delinquent activities (Brook, Arencibia-Mireles, Richter, \& Whiteman, 2001).

The psychological issues are actually sharing experiences that should be given serious attention. When these issues are not addressed and taken seriously by parents, teenagers would feel they are not getting the recognition and attention that they need and eventually they will lose meaning in life. These issues ultimately may be associated with emotional disorders that cause adolescents to be delinquents. The failure of the authorities to give attention to the disorder elements in terms of the adolescents' psychology can also cause them to suffer from mental disorders. Previous research has shown that there is a significant relationship between mental health problems with delinquent behaviors (Huizinga et al., 2000). People with mental disorders have a high propensity to engage in delinquent behaviors. Similarly, McCord and colleagues (2003) found that adolescents who have emotional disorders would have a high tendency to get involved with activities that are badly chosen such as drug use.

Based on the findings of this study, it was found that the main cause for the study participants being involved with delinquency is the desire for having love and affection from significant people especially their parents and family. If they did not get the desired love as they sought, they would find someone who can meet those needs. During these fragile times, they would be taken advantage by certain irresponsible and thoughtless people. In accordance with the study conducted by Henry, Tolan, \& Gorman-Smith, (2001), it is found that teenagers who come from frail family ties will often find themselves getting involved in delinquent behaviors.

Results from this study also show that teenagers get engaged with juvenile delinquency because they want to find happiness, satisfaction and joy due to pressured life. They choose a way out by doing negative behaviors such as engaging in sexual intercourse, the use of ecstasy pills and drink alcohol in order to relieve stress. As Brook and colleagues (2001) described in their study, those who do not have strong family ties and affection often susceptible to negative things such as taking the prohibited substances.

The prominent feelings of adolescent delinquent in this study involve the feelings of hatred, anger, revenge, frustration, sadness, low self-esteem, trauma and depression. These sentiments are expressed towards the individuals who are the cause of destructions in their lives, including mother, father, boyfriend and certain family members. Revolting behaviors such as going against their parents and running away from home are resulted from not being able to face the challenges in life.

\section{Conclusion}

The use of Expressive Arts Therapy in this study is a new expertise that has been produced in counseling knowledge that will generate human capital development. The use of such therapy can be a module dedicated to scientific researchers in counseling, counselors, parents, teachers and other parties to continue in reaching out to teenagers in order to reduce social problems which is an issue that threatens the peace and prosperity of the nation. Due to the fact that this therapy can understand adolescents like those who were involved in this study, the modules in this therapy can be submitted to any parties concerned and delivered to the individuals involved specifically and directly with adolescents.

The use of Expressive Arts Therapy is an alternative that can be used by counseling practitioners to understand individuals who face difficulties in expressing their feelings, especially those who suffer from chronic problems and crises that cause internal trauma to an individual, especially to children and adolescents. Development in the use of this therapy is regarded as a contribution and added value of knowledge in the field of counseling itself. The findings of this study could provide a new knowledge for counseling practitioners who are interested in using this therapy.

Recognizing that fact, it is time we shift the view and track the steps of those who have been using Expressive Arts Therapy in the context of Western society and apply its use in our society, reconstructed based our own way. The findings from this study can be a trigger and catalyst for other researchers who wish to use Expressive Arts Therapy in the future.

\section{References}

Bennink, J., Gussak, D., \& Skowan, M. (2003). The role of the art therapist in a juvenile justice setting. The Art in Psychotherapy, 30, 163-173. http://dx.doi.org/10.1016/S0197-4556(03)00051-0

Brook, J. S., Brook, D. W., Arencibia-Mireles, O., Richter, L., \& Whiteman, M. (2001). Risk factors for adolescent marijuana use across cultures and across time. The Journal of Genetic Psychology, 162(3), 357-374. http://dx.doi.org/10.1080/00221320109597489 
Capaldi, D. M., \& Shortt, J. W. (2003). Understanding conduct problems in adolescence from a life-span perspective. In G. Adams, \& M. Berzonsky (Eds.), Black well handbook of adolescence. Malden, MA: Black well.

Cashwell, C. S., \& Vacc, N. A. (1996). Family functioning and risk behaviors: Influences on adolescent delinquency. School Counselor, 44, 105-115.

Creswell, J. W. (1998). Qualitative inquiry and research design: Choosing among five traditions. Thousand Oaks, CA: Sage.

Creswell, J. W. (2003). Research design: Qualitative, quantitative, and mixed method approaches. London, UK: Sage.

Creswell, J. W. (2008). Educational research: Planning, conducting and evaluating quantitative and qualitative research (3rd ed.). Upper Saddle River, NJ: Merill Prentice Hall

Deaver, S. P. (2002). What constitutes art therapy research? Art Therapy: Journal of American Art Therapy Association, 19, 23-27. http://dx.doi.org/10.1080/07421656.2002.10129721

DeLisi, M. (2005). Career criminals in society. Thousand Oaks, CA: Sage.

Dembo, R., \& Schmeidler, J. (2003). A classification of high-risk youths. Crime \& Delinquency, 49(2), 201-230. http://dx.doi.org/10.1177/0011128702251054

Dodge, K. A., Coie, J. D., \& Lynam D. R. (2006). Aggression and antisocial behavior in youth. In W. Damon, \& R. Lerner (Eds.), Handbook of child psychology (6th ed.). New York, NY: Wiley.

Dukes, S. (1984). Phenomenological methodology in human sciences. Journal of Religion and Health, 23(3), 197-203. http://dx.doi.org/10.1007/BF00990785

Farrington, D. P. (2004). Conduct disorder, aggression, and delinquency. In R. Lerner, \& L. Steinberg (Eds.), Handbook of adolescent psychology. New York, NY: Wiley.

Finn, C. A. (2003). Helping students cope with loss: Incorporating arts into group counseling. Journal of Specialists in Group Work, 28, 155-165. http://dx.doi.org/10.1080/714860157

Foster, Jones, \& Conduct Problems Prevention Research Group. (2006). Can a costly intervention be cost-effective? An analysis of violence prevention. Archives of General Psychiatry, 63, 1284-1291. http://dx.doi.org/10.1001/archpsyc.63.11.1284

Giorgi, A. (1985). Phenomenology and psychological research. Pittsburgh: Duquesne University Press.

Giorgi, A., \& Giorgi, B. (2003). Phenomenology. In J. A. Smith (Ed.), Qualitative psychology: A practical guide to research methods (pp. 25-50). London, UK: Sage.

Glueck, S., \& Glueck, E. (1950). Unraveling juvenile delinquency. New York, NY: Commonwealth Fund.

Graham, M., \& Sontag, M. (2001). Art as an evaluative tool: A pilot study. Art Therapy: Journal of the American Art Therapy Association, 18(1), 37-43. http://dx.doi.org/10.1080/07421656.2001.10129451

Grbich, C. (2007). Qualitative data analysis: An introduction. London, UK: Sage.

Hanes, M. (2000). Catharsis in art therapy: A case study of a sexually abused adolescent. Art Therapy: Journal of the American Art Therapy Association, 38(3), 70-74.

Hartz, L., \& Thick, L. (2005). Art therapy strategies to raise self-esteem in female juvenile offenders: A comparison of art psychotherapy and art as therapy approaches. Art Therapy: Journal of the American Art Therapy Association, 22(2), 70-80. http://dx.doi.org/10.1080/07421656.2005.10129440

Henry, D. B., Tolan, P. H., \& Gorman-Smith, D. (2001). Longitudinal family and peer group effects on violence and nonviolent delinquency. Journal of Clinical Child Psychology, 30, 172-186. http://dx.doi.org/10.1207/S15374424JCCP3002_5

Hirschi, T. (1969). Cause of delinquency. Berkeley, CA: University of California Press.

Howard, M. (2001). Case study: Painting in the treatment of middle class juvenile delinquents. American Journal of Art Therapy, 40(1), 40-45.

Huizinga, D., Loeber, R., Thornberry, T. P., \& Cothern, L. (2000). Co-occurrence of delinquency and other problem behaviors. Washington, DC: Office of Juvenile Justice and Delinquency Prevention.

Jabatan Kebajikan Masyarakat Malaysia (Department of Social Welfare Malaysia). (2006). Kanak-kanak terlibat 
dengan jenayah. Kuala Lumpur: JKMM

Jalal, F. H. A. (2005). Family functioning and adolescent delinquency in Malaysia. Retrieved from ProQuest Dissertations database.

Jessor, R. (Ed.). (1998). New perspectives on adolescent risk behavior. New York, NY: Cambridge University Press. http://dx.doi.org/10.1017/CBO9780511571138

Knill, P. J., Levine, E. G., \& Levine, S. K. (2005). Principles and practice of expressive arts therapy. London, UK: Kingsley.

Kroneman, L., Loeber, R., \& Hipwell, A. E. (2004). Is neighborhood context differently related to externalizing problems and delinquency for girls compared with boys? Clinical Child and Family Psychology Review, 7, 109-122. http://dx.doi.org/10.1023/B:CCFP.0000030288.01347.a2

Lantz, J., \& Gyamerah, J. (2002). Using art in short-term existential psychotherapy. Journal of Brief Therapy, $1(2), 155-162$.

Lauber, M. O., Marshall, M. L., \& Mayers, J. (2005). Gangs. In S. W. Lee (Ed.), Encyclopedia of school psychology. Thousand Oaks. CA: Sage. http://dx.doi.org/10.4135/9781412952491.n120

Lebar, O. (2006). Penyelidikan kualitatif: Pengenalan teori dan metod. Tanjung Malim. Malaysia: Penerbit Universiti Pendidikan Sultan Idris.

Lincoln, Y. S., \& Guba, E. G. (1985). Naturalistic inquiry. Newbury Park, CA: Sage.

Loeber, R., \& Stouthamer-Loeber, M. (1998). Development of juvenile aggression and violence: Some common

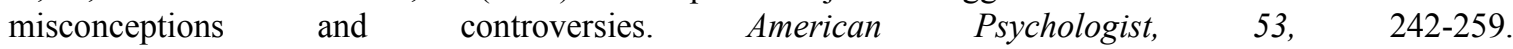
http://dx.doi.org/10.1037/0003-066X.53.2.242

Mahyuddin, R., Abdullah, M. C., \& Elias, H. (2005). Psikologi kanak-kanak dan remaja. Kuala Lumpur: Mc Graw-Hill Education.

Malchiodi, C. A. (2008). Creative interventions with traumatized children. New York, NY: The Guilford Press.

McCord, J., Widom, C. S., \& Crowell, N. A. (2003). Juvenile crime, juvenile justice. Washington, DC: National Academy Press.

Merriam, S. B (2002). Qualitative research in practice. San Francisco, CA: Jossey-Bass.

Merriam, S. B. (2001). Qualitative research and case study application in education. San Francisco, CA: Jossey-Bass.

Nasir, R., Ahmad, Z., Khairuddin, R., \& Wan Shahrazad, W. S. (2011). Family functioning, self -esteem, self-concept and cognitive distortion among juvenile delinquents. The Social Sciences, 6(2), 155-163.

Nasir, R., Ahmad, Z., Khairuddin, R., \& Yusooff, F. (2011). Depression and cognitive distortion among juvenile delinquents: Implications to rehabilitation. The International Journal of Knowledge, Culture and Change Management, 10.

Nye, F. I. (1958). Family relationships and delinquent behavior. New York, NY: Wiley.

Patterson, G. R., \& Stouthamer Loeber, M. (1984). The correlation of family management practices and delinquency. Child Development, 55, 1299-1307. http://dx.doi.org/10.2307/1129999

Patton, M. Q. (2002). Qualitative research \& evaluation methods. Thousand Oaks, CA: Sage.

Pearson, M., \& Wilson, H. (2008). Using Expressive counselling Tools to Enhance Emotional Literacy, Emotional Wellbeing and Resilience: Improving Therapeutic Outcomes with Expressive Therapies. Counselling, Psychotherapy, and Health, 4(1), 1-19.

Peorson, M., \& Wilson, H. (2009). Using Expressive Arts to Work with Mind, Body and Emotion. Theory and Practice. London, UK: Kingsley.

Potter, C. C., \& Jenson, J. M. (2003). Cluster profiles of multiple problem youth. Criminal Justice and Behavior, 30(2), 230-250. http://dx.doi.org/10.1177/0093854802251007

Riemen, D. J. (1986). The essential structure of a caring interaction: Doing phenomenology. In P. M. Munhall, \& C. J. Oiler (Eds.), Nursing research: A qualitative perspective (pp. 85-105). Norwalk, CT: Appleton-Century-Crofts.

Rogers, N. (1993). The creative connection: Expressive arts as healing. Palo Alto, CA: Science and Behavior 
Books.

Roghanchi, M., Mohamad, A. R., Mey, S. C., Momeni, K. M., \& Golmohamadian, M. (2013). The effect of integrating rational emotive behavior therapy and art therapy on self-esteem and resilience. The Arts in Psychotherapy, 40,179-184. http://dx.doi.org/10.1016/j.aip.2012.12.006

Rosen, L. (1985). Family and delinquency: Structures and function. Criminology, 23, $553-573$. http://dx.doi.org/10.1111/j.1745-9125.1985.tb00354.x

Rubin, J. A. (2001). Approaches to art therapy: Theory and technique (2nd ed.). New York, NY: Brunner Routledge.

Sabol, W. J., Coulton, C. J., \& Korbin, J. F. (2004). Building community capacity for violence prevention. Journal of Interpersonal Violence, 19, 322-340. http://dx.doi.org/10.1177/0886260503261155

Santrock, J. W. (2007). Adolescence. Boston, MA: McGraw-Hill.

Seidman, E. (1998). Interviewing as qualitative research. New York, NY: Columbia University Press.

Silverman, D. (2002). Doing qualitative research: A practical handbook. London, UK: Sage.

Simons, R. I., Wu, C. I., Lin, K. L., Gordon, L., \& Conger, R. D. (2000). A cross- cultural examination of the link between corporal punishment and adolescent antisocial behavior. Criminology, 38, 47-49. http://dx.doi.org/10.1111/j.1745-9125.2000.tb00883.x

Testa, N., \& McCarthy, J. (2004). The use of murals in preadolescent inpatient group. An art therapy approach to cumulative trauma. Art Therapy, 21(1), 38-41. http://dx.doi.org/10.1080/07421656.2004.10129323

Wadeson, H., \& Wirtz, G. (2005). The hockey/ art alliance. Art Therapy: Journal of the American Art Therapy Association, 22(3), 155-160. http://dx.doi.org/10.1080/07421656.2005.10129493

Wilson, M., \& Daly, M. (2006). Are juvenile offenders extreme future discounters. Psychological Science, 11, 989-994. http://dx.doi.org/10.1111/j.1467-9280.2006.01817.x

Yayasan Pencegahan Jenayah Malaysia (Malaysia Crime Prevention Foundation). (2009, April 12). Pecahan jenayah pesalah juvana (13-18 tahun: Jan-Feb 2009). Berita Minggu, BM2, hlm. 3

Yusoff, M. (2004). Pertimbangan kritikal dalam pelaksanaan kajian kes secara kualitatif. In Penyelidikan kualitatif: Pengalaman kerja lapangan kajian (pp. 35-56). Kuala Lumpur: Universiti Malaya.

Zaslow, M. J., \& Takanishi, R. (1993). Priorities for research on adolescent development. American Psychologist, 48, 185-192. http://dx.doi.org/10.1037/0003-066X.48.2.185

\section{Copyrights}

Copyright for this article is retained by the author(s), with first publication rights granted to the journal.

This is an open-access article distributed under the terms and conditions of the Creative Commons Attribution license (http://creativecommons.org/licenses/by/3.0/). 